http://dx.doi.org/10.4314/jae.v16i2.9

\title{
Awareness and perceptions of climate change among extension workers of Agricultural Development Programme (ADP) in Anambra State, Nigeria
}

\author{
Iwuchukwu J C and Onyeme F. N \\ (julieiwuchukwu@yahoo.com)
}

\begin{abstract}
The study sought to ascertain awareness and differences in male and female extension workers perceptions of climate change. The study was carried out in Anambra state, Nigeria. A total of forty respondents (20 males and 20 females) purposively selected from four agricultural zones in the state were used for the study. Data were analysed using percentage, mean score and t- test. All( $100 \%)$ of males and $95 \%$ of the females were married. Majority $(71.3 \%)$ of the males were in the age range of 45 to 54 years while majority $(77.9 \%)$ of the females were in the age range of $40-49$ years. The mean ages were 45 years and 44 years for the male and female extension workers respectively. Majority of the male $(60 \%)$ and female workers (68.5\%) had HND/ degree certificate and had about 4 to 6 persons in the household. Females noticed and heard about climate change earlier than their male colleagues. Male extension workers sourced information on climate change mainly from radio (100\%), newspaper (95\%) and television (80\%) while the female extension workers sourced mainly from radio (90\%), fellow extension workers (85\%) and friends/relations (70\%). There were significant differences in their perception of swamp rice production ( $t=2 . .4, p \leq 0.05)$, overgrazing of farmlands by livestock $(\mathrm{t}=-2.7, \mathrm{p} \leq 0.05)$ and high use of irrigation $(\mathrm{t}=$ $2.2, p \leq 0.05)$ as causes of climate change. There were also significant differences in their perception of high humidity $(t=2.7, p \leq 0.05)$ as indicator of climate change and high incidence of weeds $(t=-2.7, p \leq 0.05)$ as effect of climate change. Females perceived these factors more as causes, indicator and effects of climate change than males. The study emphasized on the need to educate/train both male and female extension workers generally on issues concerning climate change and specifically on the causes, indicators and effects of climate change that they are ignorant of. This is for onward transmission to their clientele, enhanced agricultural productivity and encouraging future.
\end{abstract}

Key words: awareness perceptions climate change extension workers 


\section{Introduction}

There are two major causes of climate change, namely: anthropogenic and natural causes (Ayoade (1988 and 2003) and Ojo, Ojo and Oni (2001)). Anthropogenic causes relate to those activities of man which help to change the chemical composition of the atmosphere as they relate to increasing the volume of greenhouse gases like carbon dioxide $\left(\mathrm{CO}_{2}\right)$, methane $\left(\mathrm{CH}_{4}\right)$, sulphur dioxide $\left(\mathrm{SO}_{2}\right)$ etc. that cause climate change while natural causes are associated with natural greenhouse warming and "greenhouse gases" such as carbon dioxide, methane, and chloroflorocarbons (CFCs) that cause the greenhouse effect.

Man's socio-economic activities such as deforestation, cropping, irrigation, damming of rivers to create artificial lakes, farm animals ( $\mathrm{e}, \mathrm{g}$ enteric fermentation by ruminants), destruction of carbon rich soils, addition of energy to the atmosphere through combustion of fossil fuels such as petrol, diesel and coal, gas flaring, bush burning, manufacture of cement from limestone and emission of gases by automobile exhausts lead to the production of greenhouse gases (GHGs) that cause climate change.

There are noticeable consequences of climate change in Nigeria such as intense thunderstorms, widespread floods and incessant droughts. Odey (2009) points out that climate change impacts pose great dangers with consequences such as desertification, sea level rise, flooding, water salinization, among others. Additional impacts include threat to health as rising temperature could bring about diseases such as chronic heat rashes, cerebra-spinal meningitis (CSM), stroke, malaria and other related diseases (Sagoe, 2006). Climate change will affect every citizen, every part of our environment and our natural resources.

Evidence from literature and past studies reveals that the recent global warming has influenced agricultural productivity leading to declining food production (Kurukulasuriya \& Mendelsohn, 2006; International Institute for Sustainable Development (IISD), 2007; Lobell, Burke, Tebaldi, Mastrandrea, et al. 2008). Therefore many African countries that have their economies largely based on weather-sensitive agricultural productions systems like Nigeria, are particularly vulnerable to climate change (Dinar, Hassan, Kurukulasuriya, Benhin, et al. 2006).

Although climate change impacts will affect all countries, its impacts will be differently distributed among different regions, generations, age, classes, income groups, occupations and genders (Intergovernmental Panel on Climate Change(IPCC), 2001). Climate change does not affect women and men in the same way and it has, and will have a gender-differentiated impact (Aguilar nd) .The poor (of which $70 \%$ are women), primarily but by no means exclusively in developing countries, will be disproportionately affected (Drexhage, 2006). Women, particularly in least-developed countries (LDCs) are disproportionately vulnerable. Consequently, they are likely to be faced with problems such as food insecurity, loss of livelihood, hardships due to environmental degradation that lead 
to displacement and a host of other potentially devastating economic and social consequences.(United Nations Development Programme (UNDP),2008) .

In spite of the differentiated vulnerability and impact of climate change, gender issues have been rarely addressed in relation to climate change impact in global climate change initiatives and policy meetings (UNDP,2008). Many key decisionmaking institutions related to climate change have a male-dominated hierarchical structure( Anguilar, nd) and women are still underrepresented in decision-making with respect to plans and actions to mitigate and adapt to climate change (UNDP, 2008). The assumption may be that women will benefit equally from genderneutral development interventions. Policies and programmes that ignore differential impact on gender groups are often gender blind and potentially harmful for human development.(Amu,2006). This calls for the need for sex disaggregated data and information generally and especially on critical issues like climate change so that appropriate decisions and policies related to the issue can be made.

Given the devastating effects of climate change on agriculture, It's differential impact across gender and the roles agricultural extension will play in this regard especially in helping farmers to mitigate and adapt to climate change, it becomes pertinent to assess male and female extension workers awareness and perceptions on climate change. This is with the aim to understannd their views and lapses about climate change thereby pointing at specific areas each gender needs training on. Specifically, the study examined the socio-economic characteristics of the respondents, their awareness and sources of information on climate change as well as the differences in their perceptions on causes, indicators and effects of climate change.

\section{Methodology}

The study was carried out in Anambra state, Nigeria. The population for the study consisted of all the extension workers in Anambra State Agricultural Development Programme (ANADEP). From the four agricultural zones in the state (Awka, Aguata, Anambra and Onitsha zones),five male and five female extension workers were purposively selected from each of the zones. This was to ensure equal representation of the gender in the study. Thus a total of forty respondents were used for the study.

The instrument used for the collection of data for this study was a questionnaire. Some information contained in it 44 were: actual age of the respondents which were further categorized into 35-39 years, 40-years etc, sex and marital status,. level of formal education, professional cadre in ADP and household size. Others included awareness and time(year) they noticed and heard about climate change. Also, they were asked to indicate the extent they perceive listed factors as causes, indicators and effects of climate change. Some of the variables listed under causes were bush burning, cutting down of trees, gas flaring from oil companies, etc. Variables listed under indicators were abnormal rise in temperature, excessive 
heat, drying up of streams or waters, etc. Variables listed under effects were reduced crop yield/ output, increase in diseases like malaria, stroke etc, increase in crop pests and diseases, desertification and others. A four point Likert-type scale of to a great extent'4', to a moderate extent'3', to a little extent'2' and to no extent' 1 ' was used to collect the data. The values of the scale were summed up to give 10 which was divided by 4 to give a mean score of 2.5. Any variable with mean score greater than or equal to 2.5 was regarded as either cause, indicator or effect of climate change while variable with mean score less than 2.5 was regarded otherwise.

Data were analysed with percentage mean score and t-test.

\section{Results and Discussion}

\section{Socio-economic characteristics}

Data in Table I show that equal number of male and female respondents were used for the study. The age of the respondents as shown in the table below indicates that majority $(71.3 \%)$ of the males were at the age range of 45 to 54 years while majority $(77.9 \%)$ of the females were at the age range of 40 to 49 years. Their mean ages were 44.8 and 44 years for male and female extension workers respectively. This finding shows that both the male and female extension workers were at their middle age and productive age hence they will be energetic to carry out specific tasks associated with extension work especially as regards to climate change.

Table 1 also indicates $\backslash$ that all (100\%) of the male respondents and $(95 \%)$ of the female respondents were married. Majority (61.1\%) of the males had household size of 7 to 9 persons while majority (77.8\%) of the females had household size of 4 to 6 persons. Their mean house hold size were 6 persons and 5 persons for the male and female respondents respectively. Generally, the respondents had moderate household size. The slight difference in their household size may be attributed to the fact that some of the female respondents were still single so their household size are likely to be low.

In Table 1 also, majority (Male (60\%), females (68.5\%)) had HND/ degree as their highest educational qualification. The proportion of the males that had masters degree was about $27 \%$ while only about $5 \%$ of females had masters degree. On the other hand, more females $(26.3 \%)$ had OND certificate than males $(13.3 \%)$. This tends to suggest that the male extension workers are more educated than their female counterpart. This low educational attainment of women has been described as one of the reasons for their concentration in low productive lowwage, low-skill, menial jobs in agriculture and non agriculture sectors (Voice of Child worker,1995).

Majority (63.2\%) of the males had served as extension workers for 21-25 years while about $42 \%$ of their female counterpart had worked for $16-20$ years as 
extension workers (Table 1 ). Also about $26 \%$ each represent males that had worked for 16-20 years and females that had worked for 21-25 years as extension workers. Their mean length of service as extension workers were 21 years for males and about 18 years for females. This shows that the males had more experience than females in extension work. Table 1 further shows that $40 \%$ of the male respondents and $65 \%$ of female respondents were block extension supervisors and extension agents. Also (35\%) each represent male respondents that were zonal managers /zonal extension officers and female respondents that were subject matter specialists. From the findings it can be inferred that male extension workers were concentrated more at the higher cadre while the females were concentrated more at the lower cadre. The lower educational qualification and shorter length of service of these females compared to their male counterpart (Table 1) may serve as reasons for their concentration in lower cadre of extension work. 
TABLE 1

Socio-economics characteristics of the respondents

\begin{tabular}{|c|c|c|c|c|}
\hline Characteristics & Male $\%(n=20)$ & Mean & Female $\%(n=20)$ & Mean \\
\hline $\begin{array}{l}\text { Sex } \\
\text { Male } \\
\text { Female } \\
\text { Marital status }\end{array}$ & 100 & & 100 & \\
\hline Single & & & 5 & \\
\hline $\begin{array}{l}\text { Married } \\
\text { Household size }\end{array}$ & 100 & & 95.0 & \\
\hline $1-3$ & 0 & & 11.1 & \\
\hline $4-6$ & $61-1$ & 6 & 77.8 & 5 \\
\hline $\begin{array}{l}5 \\
\text { Age }\end{array}$ & 38.9 & & 11.2 & \\
\hline $35-39$ & 14.3 & & 0 & \\
\hline $40-44$ & 14.3 & 44.8 & 55.6 & 44 \\
\hline $45-49$ & 49.9 & & 22.3 & \\
\hline $50-54$ & 21.4 & & 16.8 & \\
\hline $55-59$ & 0 & & 5.6 & \\
\hline $\begin{array}{l}\text { Highest Educational } \\
\text { Qualification }\end{array}$ & & & & \\
\hline OND Certificate & 13.3 & & 26.3 & \\
\hline HND/Degree Certificate & 60 & & 68.5 & \\
\hline Masters certificate & 26.7 & & 5.3 & \\
\hline $\begin{array}{l}\text { Length of service as } \\
\text { extension worker }\end{array}$ & & & & \\
\hline $11-15$ & 5.3 & & 31.7 & \\
\hline $16-20$ & 26.3 & & 42.2 & \\
\hline 25 & 63.2 & 18 & 26.4 & 21 \\
\hline $26-30$ & 5.3 & & 0 & \\
\hline $\begin{array}{l}\text { Carder in extension } \\
\text { work/ADP }\end{array}$ & & & & \\
\hline Zonal madger & 20 & & 0 & \\
\hline Zonal extension officer & 15 & & 0 & \\
\hline Subject matter specialist & 25 & & 35 & \\
\hline $\begin{array}{l}\text { Block extension } \\
\text { supervision }\end{array}$ & 10 & & 20 & \\
\hline Extension agent & 30 & & 45 & \\
\hline
\end{tabular}




\section{Awareness of Climate Change}

Table 2 shows that all (100\%) of both male and female extension workers were aware of climate change and had also heard about climate change. This awareness of the respondents about climate change is advantageous as it involves creation of knowledge, understanding, values, attitude, skills and abilities among individuals and social groups toward climate change for attaining a better quality environment (Ekpo and Ekpo 2011). This awareness and proper understanding of climate change may also be seen as an important step towards solution to climate change problem .

\section{Years the respondents heard and noticed climate change}

Majority $(73.7 \%)$ of the male extension workers and $55.5 \%$ of the female extension workers heard about climate change within 2000 to 2009. Also (26.4\%) of the males and 39\% of females heard it within 1990 to 1999. The mean years the respondents heard about climate change were 2005 for the males and 2002 for the females.

Table 2 further indicates that majority (61.5\%) of the male extension workers noticed that climate started changing within 2003 to 2004 while majority $(80 \%)$ of the female extension workers noticed that climate started changing within 2002 and below. The mean years the respondents noticed climate change were 2004 for the males and 1991 for the females (Table 2). The findings tend to show that both male and female extension workers noticed that climate was changing before they heard about it. Female extension workers heard about climate change 3 years earlier and noticed it seven years earlier than their male counterpart. This points at important role of women as a catalyst in specific non agriculture and agricultural tasks. It is expected that these women will display the same role in climate change issue as can be proved by their earlier knowledge and information on climate change than their male counterpart. 
TABLE 2

Awareness of climate change by the respondent

\begin{tabular}{|c|c|c|c|c|}
\hline Issue on climate change & Male (\%) $\mathbf{n}=\mathbf{2 0}$ & Mean & Female(\%) $n=20$ & Mean \\
\hline \multicolumn{5}{|l|}{ awareness } \\
\hline Aware & 100 & & 100 & \\
\hline Not aware & 0 & & 0 & \\
\hline \multicolumn{5}{|l|}{$\begin{array}{l}\text { Year heard about climate } \\
\text { change }\end{array}$} \\
\hline Heard & 100 & & 100 & \\
\hline Not heard & 0 & & 0 & \\
\hline \multicolumn{5}{|l|}{$\begin{array}{l}\text { Year heard about climate } \\
\text { change }\end{array}$} \\
\hline Below 1990 & 0 & & 5.6 & \\
\hline 1990-1994 & 15.8 & & 0 & \\
\hline 1995-1999 & 10.6 & & 39.0 & \\
\hline $2000-2004$ & 5.3 & & 22.2 & \\
\hline 2005-2009 & 8.4 & 2005 & 33.3 & 2002 \\
\hline \multicolumn{5}{|l|}{$\begin{array}{l}\text { Year noticed climate } \\
\text { change }\end{array}$} \\
\hline Below 2000 & 0 & & 40.0 & \\
\hline 2001-2002 & 38.5 & & 40.0 & 1991 \\
\hline 2003-2004 & 61.5 & 2004 & 10.0 & \\
\hline $2005-2006$ & 0 & & 10.0 & \\
\hline
\end{tabular}

Source: field survey 2011

\section{Respondents sources of information on climate change}

The respondents major sources of information on climate change was radio as indicated by all $(100 \%)$ of the male and $(90 \%)$ of the female extension workers (Table 3). Other sources of information for the males were newspaper $(95 \%)$, television $(80 \%)$ fortnightly training (FNT) $(60 \%)$, workshops/seminars/trainings $(55 \%)$ and fellow extension workers $(50 \%)$. The female extension workers other sources of information were: fellow extension workers $(85 \%)$, friends/relations $(70 \%)$, television (65\%), FNT (65\%) and newspapers (50\%). It is evident from the findings that both categories of respondents sourced information on climate change mainly through formal sources. However, female extension workers also sourced information on climate change from informal sources. This finding corroborates Egbule (2010) who stated that the major sources through which the farmers in Niger delta region of Nigerian receives information on climate change were radio/television, Newspapers and friends. 
TABLE 3

Respondents sources of information on climate change

\begin{tabular}{lll}
\hline Sources of information & Male\% & Female\% \\
\hline Fortnightly training (FNT) & 60.0 & 65.0 \\
Radio & 100.0 & 90.0 \\
Fellow extension workers & 50.0 & 88.0 \\
MTRM & 45.0 & 45.0 \\
Ministry of agriculture & 40.0 & 45.0 \\
Workshops/seminars /training & 55.0 & 45.0 \\
Newspaper & 95.0 & 50.0 \\
Friends/relations & 20.0 & 70.0 \\
Primary/secondary school children & 10.0 & 15.0 \\
Television & 80.0 & 65.0 \\
Town crier/village/town meetings & 20.0 & 30.0 \\
Text messages from different networks & 20.0 & 35.0 \\
Students from tertiary institutions & 15 & 20.0 \\
Telephone calls & 15 & 10.0 \\
Computer i.e. mail & 22.2 & 15.0 \\
Self initiative & 20.0 & 30 \\
\hline
\end{tabular}

${ }^{*}$ multiple responses source field survey 2011

\section{Perceptions of respondents on causes of climate change}

Table 4 shows that gas flaring from oil companies $(M=3.4)$ and cutting down trees $(\mathrm{M}=3.4)$ were perceived most by male and female extension workers respectively as causes of climate change .Other causes of climate change as indicated by the male respondents were: high temperature due to ozone layer depletion ( $M=3.3)$, cutting down of trees $(M=3.2)$, gases released from industries $(M=3.1)$, bush burning $(M=3.0)$, crude oil spillage $(M=2.6)$ and burning of fossil fuels from vehicles $(M=2.6)$.

The female respondents perceived bush burning $(M=3.1)$, high temperature due to ozone layer depletion $(M=3.1)$, overgrazing of farm lands by livestock $(M=3.0)$, use of pesticides $(M=3.0)$, use of herbicides $(M=2.9)$, gas flaring from oil companies $(M=2.9)$, gas released from industries $(M=2.8)$, crude oil Spillage ( $M$ $=2.8)$ and use of fertilizer $(\mathrm{M}=2.6)$ as causes of climate change. (Table 4). This shows that both male and female extension workers perceived or attributed change in climate to anthropogenic causes which are those activities of man that help to change the chemical composition of the atmosphere. They did not see it as natural phenomenon as can be proved by their lower mean score on this factor (male and females $M=2.0$ ). These findings are partly in support of the fact that major causes of climate change are anthropogenic and natural (Ayoade 1988 and 2003, Ojo, Ojo and Oni, 2001). 
Also in Table 4, there were significant differences in the perception of male and female extension workers on the following causes of climate change: swamp rice production ( $\mathrm{t}=-2.4)$, overgrazing of farm land by livestock $(\mathrm{t}=-2.7)$, high use of irrigation ( $t=-2.2)$, use of fertilizer ( $t=-2.2)$, use of pesticides $(t=-3 \%)$ and use of herbicides $(t=-3.1)$. This indicates that the female respondents perceived these factors more as causes of climate change than their male counterparts. This can be proved by the higher mean scores of the female than the males on these causes in Table 4. This finding seem to agree with the fact that women are on the front line of climate change. This could be reasons why the stakes are higher than ever to empower women and ensure that they are equal actors and benefactors in order to truly mitigate and cope with climate change (www.unifern//modules/footer..php online3).

TABLE 4

Mean score and t-value of male and female extension workers perceptions of causes of climate change

\begin{tabular}{|c|c|c|c|c|c|}
\hline & $\begin{array}{l}\text { Male } \\
\text { (mean) }\end{array}$ & SD & $\begin{array}{l}\text { Female } \\
\text { (mean) }\end{array}$ & SD & T-value \\
\hline Bush burning & 3.0 & 0.76 & 3.1 & 0.89 & -0.4 \\
\hline Cutting down of trees & 3.2 & 0.70 & 3.4 & 0.67 & -0.7 \\
\hline Gas flaring from oil companies & 3.4 & 1.04 & 3.0 & 1.0 & 1.5 \\
\hline Gases related from industries & 3.2 & 1.07 & 2.8 & 0.89 & 1.1 \\
\hline Burning of $f$ ire wood for cooking & 2.0 & 0.65 & 2.3 & 0.72 & 1.2 \\
\hline Crude oil spillage & 2.6 & 0.88 & 2.8 & 0.96 & -0.8 \\
\hline Swamp rice production & 1.5 & 0.89 & 2.3 & 1.13 & $2.4^{*}$ \\
\hline High temperature due to ozone layer depletion & 3.3 & 1.03 & 3.1 & 1.03 & 0.8 \\
\hline Overgrazing of farmlands by livestock & 2.2 & 1.04 & 3.0 & 0.94 & $-2.7^{*}$ \\
\hline High use of irrigation & 1.7 & 0.59 & 2.2 & 0.83 & $-2.2^{*}$ \\
\hline Burning of fossil fuel from vehicle & 2. 6 & 0.76 & 2.3 & 0.91 & 0.8 \\
\hline Use of fertilizers & 1.6 & 0.76 & 2.6 & 0.95 & $-2.2^{*}$ \\
\hline Use of pesticides & 2.1 & 0.71 & 3.0 & 0.83 & $-3.6^{*}$ \\
\hline Use of herbicides & 2.1 & 0.72 & 2.9 & 0.91 & -3.1 \\
\hline Digestive process of ruminants & 1.6 & 0.94 & 2.6 & 0.99 & -1.8 \\
\hline Nothing /natural phenomenon & 2.0 & 1.28 & 2.0 & 1.27 & 0.0 \\
\hline
\end{tabular}

Significant at $P \leq 0.05 ; \quad$ Source:field survey 2011 


\section{Perceptions of Respondents on Indicators of Climate Change}

Data in Table 5 indicate that the male extension workers perceived all the factors in the table as indicators of climate change while their female counterpart perceived all but 'drying up of steams/water' $(M=2.4)$ as indicators of climate change. Prominent among these factors that were perceived as indictors of climate change by the males were: abnormal rise in temperature $(M=3.5)$, excessive sunlight/ heat $(M=3.3)$, widespread floods $(M=3.1)$ and irregular rainfall pattern (M 3.0) while that of females were: excessive sunlight/heat ( $M=$ 3.6), abnormal rise in temperature $(M=3.4)$ and irregular rainfall pattern $(M=3.2)$.

Among all these factors in Table 5, only 'high humidity' ( $t=-2.8)$ was perceived statistically different by male and female extension workers as indicator of climate change. This further shows that the females perceived this factor (high humidity) more than their male counterpart as indicator of climate change. From the foregoing it can be inferred that there was slight difference in the perception of male and female extension workers on indicators of climate change.

\section{TABLE 5}

Mean score and t-value of male and female extension workers perceptions' of indicators of climate change

\begin{tabular}{llllll}
\hline Indicators & $\begin{array}{l}\text { Male } \\
\text { mean }\end{array}$ & SD & $\begin{array}{l}\text { Female } \\
\text { mean }\end{array}$ & SD & T-value \\
\hline Abnormal rise in temperature & 3.5 & 0.69 & 3.4 & 0.75 & 0.2 \\
Excessive sunlight/heat & 3.3 & 0.64 & 3.6 & 0.69 & -1.4 \\
High humidity & 2.6 & 0.60 & 3.2 & 0.67 & -2.7 \\
Dying up of steams/waters & 2.7 & 1.09 & 2.4 & 0.88 & 0.8 \\
Irregular rainfall patters & 3.0 & 0.88 & 3.2 & 0.81 & -0.6 \\
Intense thunder storm & 2.6 & 0.82 & 2.7 & 1.03 & -0.3 \\
Widespread floods & 3.1 & 0.91 & 2.9 & 0.99 & -0.7 \\
Drought & 2.8 & 0.85 & 2.7 & 0.87 & 0.0 \\
Overflow/rise in sea level & 2.9 & 0.93 & 2.9 & 0.94 & -0.1
\end{tabular}

Significant at $P \leq 0.05$; Source: field survey 2011 


\section{Perceptions of respondents on effects of climate change}

Table 6 shows that reduced crop yield/output $(M=3.3)$ was perceived most by male extension workers while rapid depletion of soil fertility $(M=3.2)$ was perceived most by their female counterpart as effects of climate change. Other factors that were perceived by both categories of respondents as effects of climate change were: desertification ( male $(M=3.1)$, female $(M=2.8)$ ), migration of people/ farmers (Male and Female $M=3$ ), erosion (male $(M=3.0)$, female $(M=$ $3.2)$ ), increase in diseases like malaria, stroke (Male $(\mathrm{M}=2.9)$, Female $(\mathrm{M}=$ 2.7)), Increase in chronic heat rashes (male ( $M=2.9$ ), female (M 3.0)), death of aquatic organisms (male $(\mathrm{M}=2.9)$, female $(\mathrm{M}=2.7)$ ), water salinization (male ( $M=2.8)$, female $=(2.9)$ ), rapid depletion of fertility of the soil (male $(M=2.7)$, female $(M=3.2)$ ), evolvement of strange pests and diseases of crops and livestock (male $(M=2.6)$, female $(M=2.5)$ ) and increase in crop pests and diseases (male $(M=2.5)$, female $(M=2.8)$ ). This finding supports the fact that climate change will affect every citizen, every part of environment and our natural resources

It is not surprising that high incidence of weeds $(M=2.6)$, high livestock disease infestation $(F=2.5)$, and losses of crops under preservation./storage, $(M=2.5)$ were perceived by only female extension workers as effects of climate change. This is because women are the main producer of the world staple crops (Pimbert, 2009). In Sub -Saharan African they physically produce 70 to $80 \%$ of domestic food crops and also play key role in post harvest operations by ensuring preservation and sustainable use of biodiversity of plants, animals and farming systems (Akpabio, 2005).

Table 6 further shows that there was significant difference on only the perception of male and female extension workers on 'high incidence of weed' ( $\mathrm{t}=-2.7)$ as effects of climate change. Thus indicating that females perceived it more than their male counterpart as an effect of climate change. This can be proved by the higher mean score of the females than the males on this factor in Table 6. The engagement of women (which female extension workers are not exception ) in weeding operations in the farm especially in developing countries like Nigeria may have given them more insight on how climate change affects it. 
TABLE 6

Mean score and $t-$ value of male and female extension workers perceptions of effects of climate change

\begin{tabular}{|c|c|c|c|c|c|}
\hline Effect of climate change & $\begin{array}{l}\text { Male } \\
\text { (mean) }\end{array}$ & SD & $\begin{array}{l}\text { Female } \\
\text { (mean) }\end{array}$ & SD & T-value \\
\hline Reduced crop yield/output & 3.3 & 0.66 & 3.0 & 0.61 & 1.8 \\
\hline Increased in disease like malaria stroke & 2.9 & 0.67 & 2.7 & 0.75 & 0.9 \\
\hline Increase in chronic heat/rashes & 2.9 & 0.75 & 3.0 & 0.71 & -0.4 \\
\hline Increase in crop pests and diseases & 2.5 & 0.69 & 2.8 & 0.64 & -1.4 \\
\hline Desertification & 3.1 & 0.83 & 2.8 & 0.91 & 1.1 \\
\hline Water salinization & 2.8 & 0.85 & 2.9 & 0.91 & -0.5 \\
\hline Rapid depletion of soil fertility & 2.7 & 0.99 & 3.2 & 0.81 & -1.7 \\
\hline Migration of people/farmers & 3.0 & 1.03 & 3.0 & 0.91 & 0.0 \\
\hline Death of aquatic organisms & 2.9 & 0.94 & 2.7 & 0.75 & 0.8 \\
\hline Delayed growth and maturity of livestock & 2.1 & 0.51 & 2.3 & 0.72 & -1.0 \\
\hline $\begin{array}{l}\text { High crop and livestock disease infestation/out } \\
\text { break }\end{array}$ & 2.1 & 0.55 & 2.5 & 0.76 & -1.9 \\
\hline $\begin{array}{l}\text { Evolvement of strange pests and diseases of } \\
\text { crop and livestock }\end{array}$ & 2.6 & 0.78 & 2.5 & 0.95 & 0.4 \\
\hline $\begin{array}{l}\text { Losses of crops under preservation/storage } \\
\text { high incidence of weeds }\end{array}$ & $\begin{array}{l}2.0 \\
1.8\end{array}$ & $\begin{array}{l}0.65 \\
0.86\end{array}$ & $\begin{array}{l}2.5 \\
2.6\end{array}$ & $\begin{array}{l}1.19 \\
1.0\end{array}$ & $\begin{array}{l}-1.5 \\
-2.7^{*}\end{array}$ \\
\hline
\end{tabular}

Significant at $P \leq 0.05$ source: field survey 2011

\section{Conclusion}

The study has shown that the male extension workers were more educated, had higher length of service and occupied top cadre/positions in extension work/ADP than their female counterpart. The females noticed and heard about climate change earlier than these males. Their perceptions on causes, indicator and effects of climate change were also higher than that of the male extension workers.

\section{Recommendations}

1. Issues related to climate change especially mitigation, adaptation, policy/programme development and implementation should be gender sensitive. In this way feelings and views of different gender can be examined and incorporated in decision making about climate change. This consensus will lead to invention of holistic and workable solution to climate change.

2. Women should be educated and given opportunity to assume leadership positions in different spheres of life like their male counterpart and 
especially in agriculture and climate change issue. This is because they may be said to be powerful agents of change irrespective of their low socioeconomic statuses in the society. Their leadership in agriculture and climate change is critical as they can help to accelerate processes that can be used to deal with climate change through their agricultural, domestic and onerous tasks that directly or indirectly contribute to climate change and attachment to virtually every members of their families and society at large. Empowering them means empowering the society at large towards a justifiable fight against climate change.

3. There is need to educate/train both male and female extension workers generally on issues concerning climate change and specifically on the causes, indicators and effects of climate change that they are ignorant of.. This is for onward transmission to their clientele. These capacities built among extension workers and farmers will contribute immensely towards mitigation and adaptation to climate change for enhanced agricultural productivity and encouraging future.

\section{References}

Akpabio, . I . (2005).Women and agricultural development inNwachukwu I and Onuekwusi .G ( eds) Agricultural Extension And Rural Development. 225 228 Enugu Snaap Press LTD.

Amu , J. N.(2009). The Role of Women in Ghana's Econom.y. Ghana, Graghix. andVirginieViamnick .

Anguilar $L(n d)$. www.gender and environment.org.

Ayoade, J.O (1988): Introduction to climatology for the Tropics Ibadan .Spectrum Books.

Ayoade, J.O (2003): Climate Change . Ibadan, Vantage Publishers.

Dinar, A, Hassan, R, Kurukulasuriya, P, Benhin, J \& Mendelsohn, R, (2006). The policy nexus between agriculture and climate change in Africa. A synthesis of the investigation under the GEF/WB Project: Regional climate, water and agriculture: Impacts on and adaptation of agro-ecological systems in Africa. CEEPA Discussion Paper No. 39. Centre for Environmental Economics and Policy in Africa, University of Pretoria.

Drexhage,(2006) in Anguilar L (nd). www.gender and environment.org.

Egbule C. (2010). Indigenous and emerging adaptive agricultural technologies to climate change in the Niger Delta region of Nigeria. An MSc research finding paper in the department of agricultural extension, University of Nigeria, Nsukka. 
Intergovernmental panel on climate change (IPCC) (2007) Climate change impacts, Adaptation and vulnerability in Third Assessment Report of the Intergovernmental Panel on Climate Change Parry, M. L. Canziani, O. F. Palutikof, J. P, Vanderlinden, P. J, and Hasson C. E. (eds). United Kingdom, Cambridge University Press, pp. 80-96

International Institute for Sustainable Development (IISD), (2007). Community based adaptation to climate change. A Summary of the Second International Workshop on Community-Based Adaptation to Climate Change. IISD Reporting Services.

Kurukulasuriya, P \& Mendelsohn, R, (2006). A Ricardian analysis of the impact of climate change on African cropland in CEEPA. Discussion Paper No.8. Centre for Environmental Economics and Policy in Africa, University of Pretoria.

Lobell, D. B. Burke, M. B, Tebaldi C Manstrandrea, M. D, Fakon, W. P. \& Naylor R. L. (2008). Prioritizing Climate change adaptation needs for food security in 2030 International journal of science vol 31 (9), pp. 60-71.

Odey, J. (2009) Efforts to combat climate change. A speech delivered by Honourable Minister of environment on 2009 world environment Day. Economic Confidential, June 2009.

Ojo, O; Ojo, K and F. Oni (2001): Fundamentals of Physical and Dynamic Climatology. Lagos, SEDEC Publishers.

Pimbert, . M. (2009). Women and food sovereignty. LEISA Magazine. 25( 3), pp.69, September,2009.

Sagoe, R.. (2006). Crops research institute, kumasi: A report prepared for environmental protection agency (EPA), Accra-Ghana, accessed from rgn1@psu.edu on 17 ${ }^{\text {th }}$ April, 2011

United Nations Development Programme (UNDP) (2008) . Gender and Climate change :impact and adaptation. UNDP.Asia- Pacific gender community practice annual learning workshop. Negombo, srilankar, 24-26 September.

United nations framework convention on climate change (UNFCCC) (2008). Challenges and Opportunities for mitigation in the agriculture sector. Marisa B (ed) Technical Paper. Copenhagen, Denmark .

Voice of Child Workers (1995) Economic Participation of women: Country Briefing paper women in Nepal Issue No 25

www.unifern//modules/footer...php online3. retrieved on $10^{\text {th }}$ December, 2011. 